\title{
An Artist and a Writer: YA Literature by Anna Höglund
}

\author{
Annbritt Palo ${ }^{1}$ D Anna Nordenstam ${ }^{2}$ D
}

Accepted: 25 August 2021 / Published online: 24 September 2021

(c) The Author(s) 2021

\begin{abstract}
This article highlights the interpictorality in two YA books by the Swedish writer and illustrator Anna Höglund, Om detta talar man endast med kaniner [This Is Something You Only Talk About with Rabbits] (2013) and Att vara jag [To Be Me] (2015). The analysis of the visual intertextuality between pieces of artwork by Peter Tillberg, Frida Kahlo, Lena Cronqvist, Richard Bergh and René Magritte and five pictures from Höglund's books thematises school, body and identity. The discursive positioning in the artworks and in Höglund's pictures directs the readers in their decoding of Höglund's text, offers possibilities in their interpretations and challenges the adolescent readers to make connections across different formats, such as text and image, and between different images.
\end{abstract}

Keywords YA literature · Anna Höglund · Art · Visual intertextuality · Interpictorality

Using art in picturebooks is neither a new nor an uncommon phenomenon. Many picturebooks in the twenty-first century introduce young readers to well-known artists and artworks, as well as to artistic styles. The Noisy Paint Box: The Colors and Sounds of Kandinsky's Abstract Art by Barb Rosenstock and Mary Grandpre (2014), Magritte's Marvelous Hat by D. B. Johnson (2012), Uncle Andy's: A Faabbbulous Visit with Andy Warhol by James Warhola (2005) and Frida Kahlo: The Artist Who Painted Herself by Margaret Frith and Tomie de Paola (2003) are just a selection of picturebooks introducing artists and artworks to young readers. Just like YA

\footnotetext{
Annbritt Palo is an Associate Professor in Swedish and Education at Luleå University of Technology, Sweden. She is primarily interested in issues of literature, literature and education, gender, intersectionality, media literacy and curriculum theory. Anna Nordenstam is a Professor of Comparative Literature at the University of Gothenburg, Sweden. Her research interests are children's and YA literature, literature and reading, and comics.
}

Annbritt Palo

Annbritt.Palo@1tu.se

1 Luleå University of Technology, Luleå, Sweden

2 University of Gothenburg, Gothenburg, Sweden 
novels, picturebooks might also forge "a better understanding of canonical material" (Bright, 2011, p. 40), especially if one agrees with the statement that "literacy (...) can be seen to mean cultural literacy, of which art history is a component" (Mitchell, 1990 , p. 841). In other words, picturebooks prepare young readers for highly complex visual and verbal texts. However, Philip Nel (2015) states that adults with some knowledge in art history might make visual connections between the art in a picturebook and specific paintings but that "Children-having a lesser degree of cultural awareness than those adults who write about and create such picturebooks-may experience these works quite differently than adults do" (p. 268). Therefore, using art, or visual intertextuality in picturebooks, goes beyond a merely educational purpose, that is to make young readers learn about art history. Aesthetics as art and literature give resistance and offer readers new perspectives, defamiliarisation and doubt (Biesta, 2017). Art suggests "that there is something to see that is worth seeing, but indicates that one person actually believes that there is something to see that is worth seeing by another person" (Biesta p. 44). Bildung, or self-cultivation and education, can be seen as a process or a reflective tool, in other words, as "a possibility" (Blok Johansen, 2019, p. 47).

In this article, the overarching aim is to argue that the way of using art in two YA books by the Swedish writer and illustrator Anna Höglund, Om detta talar man endast med kaniner [This Is Something You Only Talk About with Rabbits] and Att vara jag [To Be Me] not only offers the readers aesthetic expressions of new as well as of older classical artworks, but also challenges the readers to search for possible pathways in their readings of the iconotext, the text and the image (Hallberg, 1982). We endeavour to show that the visual intertextuality in the two YA books Om detta talar man endast med kaniner and Att vara jag by Anna Höglund offers such possibilities. Höglund's pictures offer both resistance and new perspectives when interpreting the verbal texts, and recognition and defamiliarisation for readers who are acquainted with the artworks referred to by Höglund's strategy of using interpictorality. This study analyses the interpictorial relation between pieces of artworks and five pictures from Om detta talar man endast med kaniner and Att vara jag. The interpictorial relationship focuses on discursive positioning as expressed in Höglund's pictures and in the artworks that we distinguish as visual intertexts. The function of art in YA literature is foregrounded in the discussion which attempts to answer the question: What can visual intertextuality bring to YA literature?

\section{Anna Höglund, Writer and Artist}

Anna Höglund (b. 1958) is an artist, illustrator and author of books for children and teenagers - in other words, what could be called an "authorstrator" (Salisbury 2012/2008, p. 23). Höglund has collaborated with a number of well-known Swedish writers of children's literature, such as Barbro Lindgren, Ulf Stark, Gunnar Lundkvist and Eva Susso. In 1982, her first book Sagan om pannkakan [The Pancake Story] was published. With four picturebooks about the teddy bears Mina and Kåge (1995-2005) for children 3-6 years old, her authorship has been one of the most important in the field of children's literature in Sweden. The existential books about 
Mina and Kåge, thematising the loneliness of Mina, after her husband Kåge has left her in order to travel around the world, have also appealed to an adult readership.

Höglund's works include drama and comics. She has received Swedish and international awards, amongst others the Zilveren penseel, the Deutscher Jungendliteraturpreis, the Pier Paolo Vergerio European Prize, the Astrid Lindgren Prize, and the Carl von Linné Plaque. Höglund has been a member of the jury of the Astrid Lindgren Memorial Award prize and she has authored or co-authored more than 30 books. Some of these books have been translated into English and other languages, for example and Kan du vissla Johanna? (Can You Whistle, Johanna?), with text by Ulf Stark. She is also represented at the museums of art in Stockholm and Gothenburg. For this study, interpictorality, or visual intertextuality, is a key concept in the analysis of five pictures from Höglund's books, along with discursive positionings, which are expressed in the artworks have been distinguished in the analysis.

\section{Höglund's YA Books}

With the two YA books, Om detta talar man endast med kaniner from 2013, and Att vara jag from 2015, Höglund thematically_verbally and creatively-explores existential aspects of being young. The targeted readership for these books is young adults. According to the publisher, Lilla Piratförlaget, the readers are 12-15-yearolds and the books are categorised as YA literature by the Swedish Institute of Children's Literature. The books have the format of a YA book: $16.5 \times 22.5 \mathrm{~cm}$ with hard covers. As is common in picturebooks, there is one painted picture per spread, and the paper is of good quality. The settings of the verbal text are similar to poetry, with a few lines on the page, There is no pagination provided. However, Höglund's books offer a new form of YA books, previously not seen in the Swedish context. They can also be seen as a form of crossover literature, seemingly investigating the boundaries between different media.

Om detta talar man endast med kaniner consists of 56 pages. Out of the 56 pages there are 31 pictures of varying sizes, most in watercolour. More than half of the pages are full-page pictures with no text. Att vara jag, on the other hand, encompasses 80 pages, divided into five chapters, an epilogue and a "list of references". There is a total of 47 pictures in different sizes and two comics. There are between 2 and 24 pages per chapter, and the number of pictures per chapter varies. No pagination is provided, but in structure Att vara jag resembles a novel. The pictures are equally important to the narrative in both books.

In Om detta talar man endast med kaniner, the protagonist is a teenager portrayed as a rabbit. The visually gender-neutral, nameless teenager is feeling different, which is expressed through symbolism. The book thematises identity, loneliness, futility, sensibility, and the longing for fellowship. In 2013, it was awarded Snöbollen for the best picturebook of the year, and it has been awarded the German Children's Literature Award, and the Elsa Beskow Plaque. The book has been translated into Arabic, Danish, Korean, Norwegian, Polish and Slovakian. In 2014, Höglund was interviewed about $\mathrm{Om}$ detta talar man endast med kaniner, and the book was described as one of the "boldest and most ambitious Swedish picture books (...) because it 
stands out as a picture book about and for teenagers" (Astrid Lindgren Memorial Award Wordpress, 2014). Höglund explained that pictures "can be helpful to tackle subjects that people find it hard to talk about. The way fairytales and dreams do" (Astrid Lindgren Memorial Award Wordpress, 2014).

Höglund's Att vara jag was published in 2015, and has been translated into Korean, Slovenian and Ukrainian. The protagonist is a teenage girl, Rosa, and the main theme of the novel is the self, in particular the young female self. Rosa reads Simone de Beauvoir's treatise The Second Sex and reflects upon herself and her surroundings. She also expresses herself artistically, through comics. Body, gender, sexuality and relationships are the subjects of her reflections. School is another subject as are themes of family and spare time. The book received the Astrid Lindgren Prize in 2016.

In an interview, Höglund explains her use of a collage technique: "Collage is also a great way to escape the lonely white paper. By bringing in a foreign element like a cutout, I can shake up my associations and pathways. I can surprise myself a little" (PM Gallery, 2018). The objective of an artist is likely not to cater to the needs, expectation, or decoding skills of the readers, but the outcome of the reading "is likely to have (...) intrinsic value and meaning" (Salisbury, 2012/2008, p. 36-37). Literary objects are not autonomous, transcendent objects, but part of a network of relationships. Therefore, the reading of texts is "a cocreation between actors that leaves neither party unchanged" (Felski, 2015, p. 84). The use of collage and montage in picturebooks is not unique to Höglund. According to Elina Druker (2018), "the collage techniques applied in picturebooks often generate the effect of 'defamiliarization,' helping the reader to see common objects or situations in unfamiliar or unusual ways" (p. 56). Thus, defamiliarisation might promote both insights and critical thinking.

\section{Visual Intertextuality, Text-Picture Relationship and Discourse}

The concept of intertextuality is "generally understood to connote the structural relations between two or more texts", Margarete Landwehr (2002, p. 2) concludes. As a theoretical concept, the term was coined by Julia Kristeva in 1966, and draws on Mikhail Bahktin's idea of an ongoing dialogue between texts. Michael Riffaterre (1981) states that intertextuality "oriente la lecture du texte, qui en gouverne éventuellement l'interprétation" (pp. 5-6); it orientates the reading and steers the interpretation in a certain direction. However, intertextuality is not limited to verbal texts. In an analogy, it is possible to argue that there are always other visual images in a picture, and scholars have suggested alternative notions, as shown by Beatriz Hoster Cabo, María José Lobato Suero and Alberto Manuel Ruiz Campos (2018): interpictorality, intericonicity, intervisuality, transpictorality, and so on (Hoster Cabo et al., pp. 92-93). Hoster Cabo et al. analyse the relation between pictures in picturebooks, as it enables readers "to get a better access to the overall meaning of the literary work" (p. 93). The notion of interpictorality is used "whenever references of images to other images are analyzed" (p. 93). 
The text-picture relationship in picturebooks has been thoroughly discussed by scholars like Perry Nodelman (1988), Joseph H. Schwarcz (1982), Lawrence R. Sipe (1998), Maria Nikolajeva and Carole Scott (2006), and Nina Christensen (2018), among others. Text and pictures can "take on a meaning that neither possesses without the other" (Nodelman, p. 221), be congruent or deviant (Schwarcz, p. 15), or change the reader's interpretation of the words, or of the pictures, thus interacting synergetically (Sipe, p. 98). Christensen distinguishes between different types of text-picture relationships, as do Nikolajeva and Scott. While Christensen distinguishes between symmetrical, contrasting and complementary text-picture relationships, Nikolajeva and Scott also add the counterpointing interaction, that is when text and picture communicate a meaning beyond what text, or picture will achieve on its own (pp. 225-226).

On the subject of art in picturebooks, Karen Coats (2012/2008) suggests that "postmodern picturebooks provide a key entry point into the self-fashioning in contemporary society" (p. 76), and that "cultural and visual literacies and narrative patterns" (p. 76) function as scaffolding for identity. Regarding art in literature for young readers, Evelyn Arizpe, Jennifer Farrar, and Julie McAdam (2018) underline the significance of images, as the readers' "recognition of the contesting discourses at work in picturebooks can create opportunities for critical engagement by encouraging readers to scrutinize texts as deliberately constructed (and de-constructable) objects" (p. 376). A reader who is not familiar with art is unlikely to discern the visual-interpictorial - references, but that reader will have to rely on what Kathy Unrath and Mick Luehrman (2009) call "the immediate visual and emotional perception" (p. 42).

According to Landwehr, "influence" and "inspiration" have been considered key terms in intertextuality (p. 2). There are, however, other aspects of intertextuality; she quotes Thaï E. Morgan (1985), who argues for a shift from "the triangle of author/work/tradition to that of text/discourse/culture" (p. 1). Discourse is the term for language in a social context. At a given moment, in a social context, certain discourses and practices are privileged, or institutionalised, while other discourses may be subordinate. In discourse analysis, the concept of positioning is used to "talk about the discursive production of a diversity of selves" (Davies and Harré, 1990, p. 47). In this article, the artworks and analysed images position themselves discursively on the themes of (1) school, and (2) gender and identity.

\section{Interpictorality—Visual Intertextuality—in Höglund's Pictures}

\section{Images of School}

In both books by Höglund, there is a picture with references to Blir du lönsam, lille vän? [Will you be profitable, my friend?], a painting from 1972 by the Swedish painter, illustrator, scenographer and sculptor Peter Tillberg (1946-2016). Tillberg's painting (Fig. 1) is photorealist in style and depicts 27 children at their school desks. All children but one are facing forwards, towards the viewer, or imaginary teacher. Even though the children are individually seated and wear tops in different colours, 


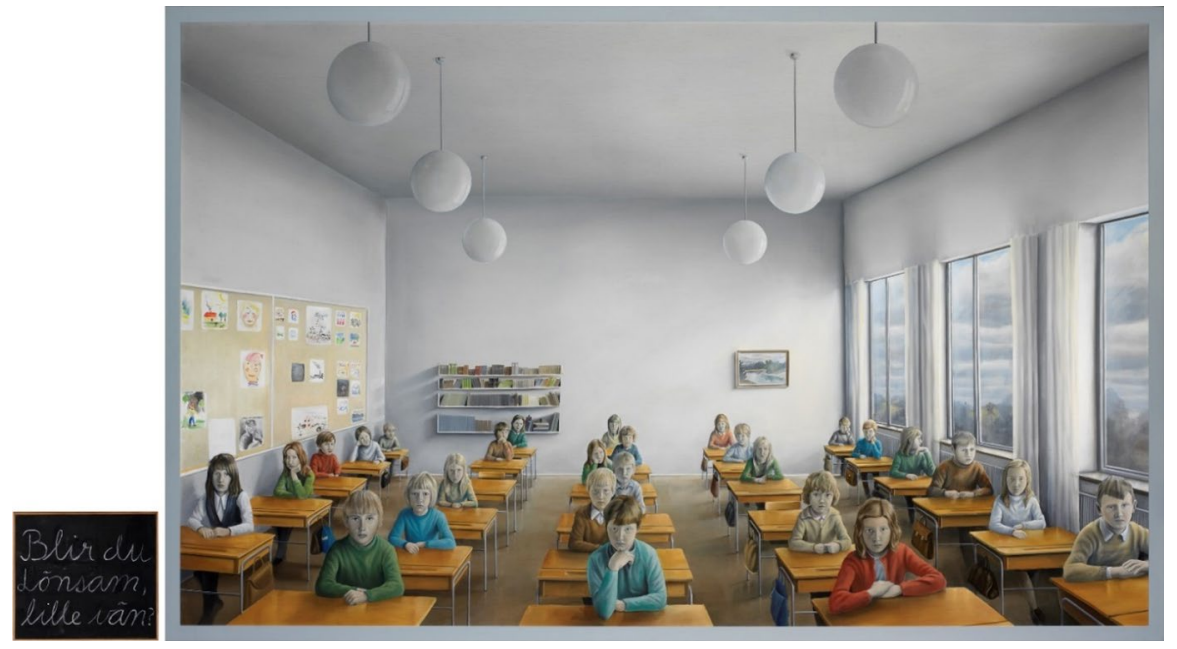

Fig. 1 Peter Tillberg's (1946-2016). Blir du lönsam, lille vän? 1972. Oil on canvas, $197 \times 316 \mathrm{~cm}$. (C) Peter Tillberg/Bildupphovsrätt 2021

from white to blue and green and brown, the children are rather uniform: sedate, similar hair styles, blank faces, ethnically seemingly homogenous. Even the only child not facing forwards but looking out of the window is visually fairly indistinguishable from the others.

The classroom is big and bright, with huge windows to the right in the painting, which means that they are to the left of the children, thus indicating that the light is adapted to right-handed pupils. A noticeboard to the left in the picture shows children's drawings, and there is a bookshelf with books and a framed landscape painting at the rear of the class.

The title of the painting-Blir du lönsam, lille vän?-paraphrases the title of a song by the Swedish musician, Peter Mosskin. In Sweden, the painting has been perceived as a contribution to a political debate, and has become a recurring image of school, depicting dejected children in a school system designed to produce profitable citizens (Thurfjell, 2011).

There are visual similarites and differences between Tillberg's painting and Höglund's school pictures in Om detta talar man endast med kaniner and in Att vara jag. As there are two school-related pictures by the same illustrator-writer, these images offer insights into visual intertextuality, or interpictorality (cf. Hoster Cabo et al.), between Tillberg's painting and Höglund's two school pictures, as well as intrapictorality, that is, similarities between Höglund's own school pictures (Figs. 2 and 3).

In Om detta talar man endast med kaniner, there is a classroom painted in pale hues (Fig. 2). Seven pupils sit at their desks with a huge window with closed white curtains to their left. The classroom is more embedded, or closed, than Tillberg's with its wide windows. The protagonist, the white rabbit, is at the front and looks bigger than the pupils behind, due to the perspective. While the other pupils' faces 


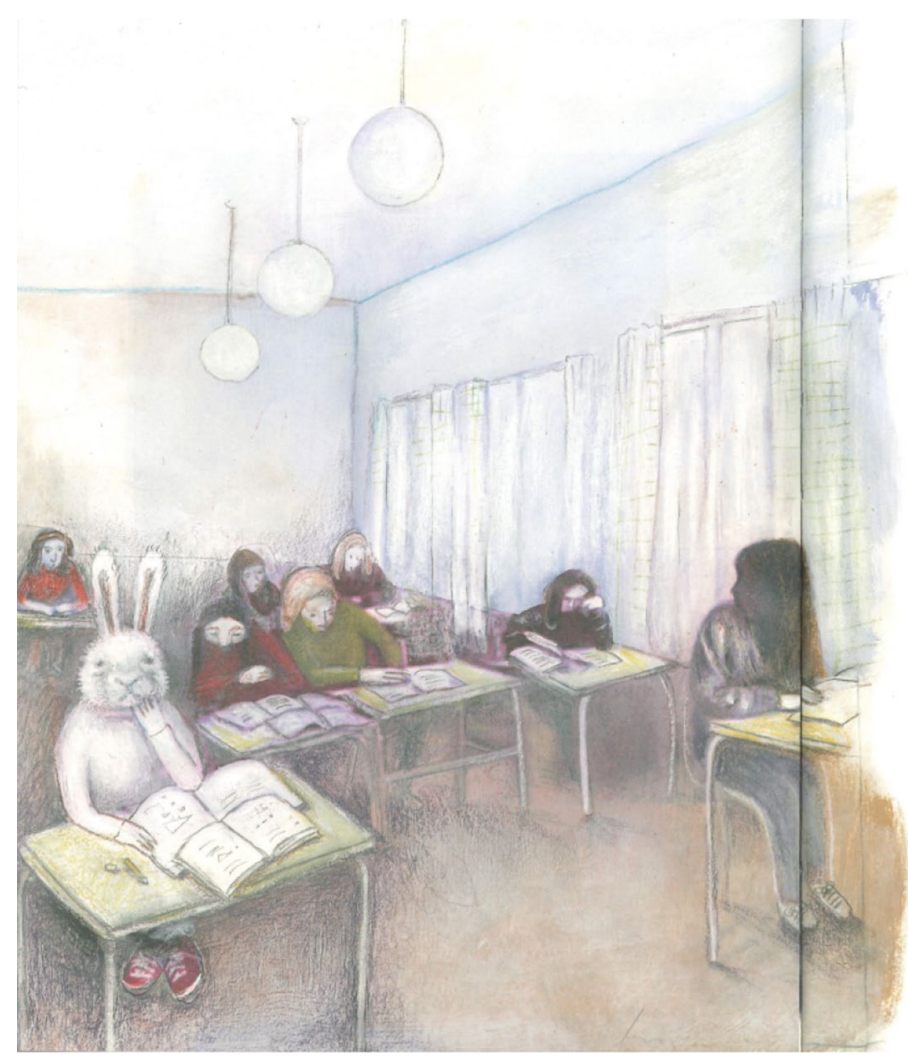

Fig. 2 From Anna Höglund's Om detta talar man endast med kaniner@ Anna Höglund

are slightly blurred, in the shadow or partially covered, the rabbit is clearly distinguishable. The other pupils are slumped at their desks, looking down at their work, except one pupil who is looking at somebody at the back of the room. Unlike the other pupils, the rabbit has red shoes, visible under the desk. Nothing in the verbal text makes an allusion to the red shoes, a traditional symbol of male power, when only the Pope or aristocrats wore red shoes or shoes with red heels, or a symbol of vanity and aspirations beyond her place, as in H. C. Andersen's tale The Red Shoes from 1845 (The Hans Christian Andersen Center, 2020), or Dorothy's red shoes in L. Frank Baum's The Wizard of $O z$ (2000/1900). The red shoes are just there, for the reader to take in and possibly interpret.

The text-picture relationship in this spread positions Höglund's picture in the category of counterpointing (cf. Christensen), that is when the picture tells a different story from the text, as it points to a meaning beyond the words on the spread:

But old habits die hard.

And there are new enemies, right?

If you think about it, nothing can be good

without being bad at the same time. 
Fig. 3 From Anna Höglund's Att vara jag@ Anna Höglund

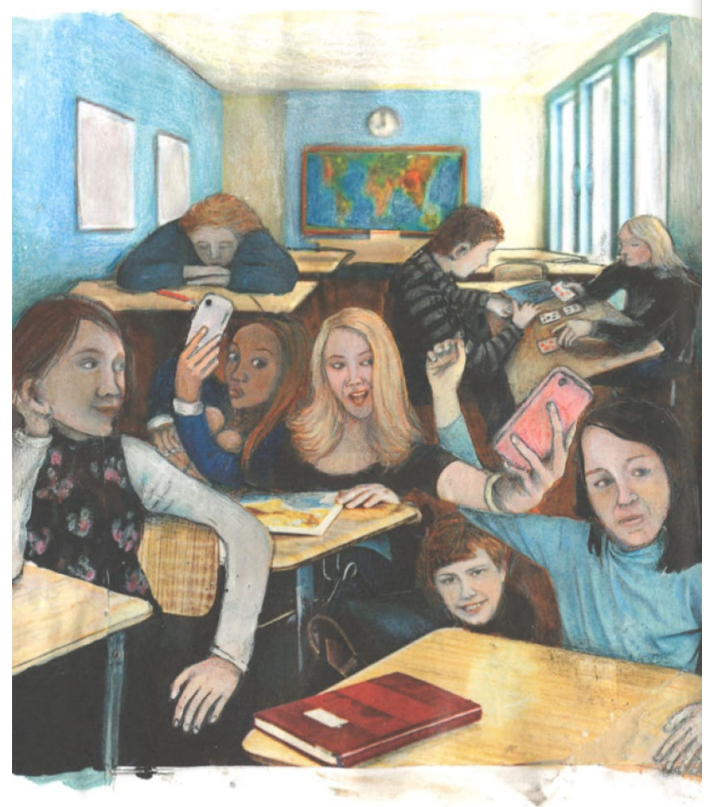

Behind what's fun

a shadow of sadness is brooding,

which can be seen if you twist it a little.

The more you twist, the more anxious it gets,

that which you just laughed at.

Wonder if it is possible to prove,

scientifically, I mean,

that everything is the opposite at the same time.

(Höglund, 2013, spread 19. Our translation.)

In Genette's (1997) terms, an earlier text, the hypotext, serves as a source of a subsequent text, a hypertext. Hoster Cabo et al. point out that the relationship between the texts is not necessarily explicit, and that "the readers have a central role of active participation, since they are required to discover the open and hidden references to other literary texts" (p. 92). A young adult reader will likely read Om detta talar man endast med kaniner without being aware of the visual textuality, or interpictorality, between Tillberg's and Höglund's pictures. Details, such as the red shoes or the human-looking hands of the rabbit-protagonist are probably observed, and interpreted only as a result of having been taught to read pictures, and can be related to the reader's general knowledge of pictures. Lopatowska et al. (2016) show in their analysis of young children's understanding of fine art paintings that children have a basic understanding of visual elements, but that their visual literacy benefits 
from being taught. Salisbury (2012/2008) points out that visual literacy "is used to describe a form of understanding of pictures that is based on a series of acquired connection-making skills that allows the picture reader to draw out literal meaning from the various signs and signals" (p. 33). Hoster Cabo et al. underscores the necessity of teaching, or practising visual literacy: "Finally, in the same way that the literary competence requires the readers' progressive understanding of the intertext, so does pictorial competence require an increase in their capacity of interpictorial reading" (p. 93). Readers of Höglund's books and of her pictures are, in other words, not provided with a skeleton key to interpreting the iconotext, but possibly with an additional tool. One could even argue that the interpictorality, once recognised, makes it impossible for readers not to interpret both the underlying artworks and Höglund's pictures.

A reader who has read both books by Höglund will need no instruction to recognise the motif of the classroom in Att vara jag. In this second picture of a classroom (Fig. 3), huge windows are to the right in the picture, so to the left of the pupils, as in both Tillberg's painting and the picture from Om detta talar man endast med kaniner. There are noticeboards to the left in the picture, and a huge map and a clock in the background. The number of pupils is significantly lower than in Tillberg's painting, only eight compared to Tillberg's 27 pupils. Furthermore, the pupils in Höglund's picture are visibly older, teenagers, and even though there are school desks, the tables are in disorder. A range of activities are ongoing: pupils taking selfies, sleeping, or playing cards. One teenager is on the floor. The girl to the left in the picture is Rosa, the protagonist of the novel. She is also the only character with whom the reader is already acquainted.

There are similarities but also significant differences between the three images. While the children in Tillberg's painting are facing forward, slightly bird's-eye view, the teenagers in Höglund's pictures are on the same level as the viewer, or imaginary teacher. In the first, there are six facing forwards and one backwards. In the second, four out of eight are facing forwards, but only two pupils look at the person in front of them. The facial expressions of the pupils are individual, and at least one of them is visibly of another ethnicity. There is also a range of activities going on in Höglund's second classroom picture. Tillberg's pupils are lined up and separated, while the pupils in Höglund's picture are leaning against each other.

There is an interpictorial relationship between Tillberg's and Höglund's school pictures, as both pictures express a view of school. In Tillberg's painting, the classroom situation turns individual children into a collective, thus robbing the children of their individuality while turning them into profitable citizens. Höglund's view of the school is different; though physically squeezed together or doing the same thing, each pupil retains his or her individuality. So does the rabbit in Fig. 2, physically different from the other pupils. Höglund's pictures (Figs. 2 and 3) refer to Tillberg's painting, while positioning themselves in a different way discursively; the school represented in Tillberg's painting strives to mould the pupils into profitable citizens, whereas the schools in Höglund's pictures allow individuals to either retain their individuality, as does the rabbit, or to seek to express themselves on an individual level, albeit superficially, while still keeping them grouped together. 
Fig. 4 Frida Kahlo (1907-

1954), Self-Portrait with

Self-cropped Hair, 1940. Oil on

canvas, $40 \times 27.9 \mathrm{~cm}$. (C) 2021 .

Digital image, The Museum of

Modern Art, New York/Scala,

Florence

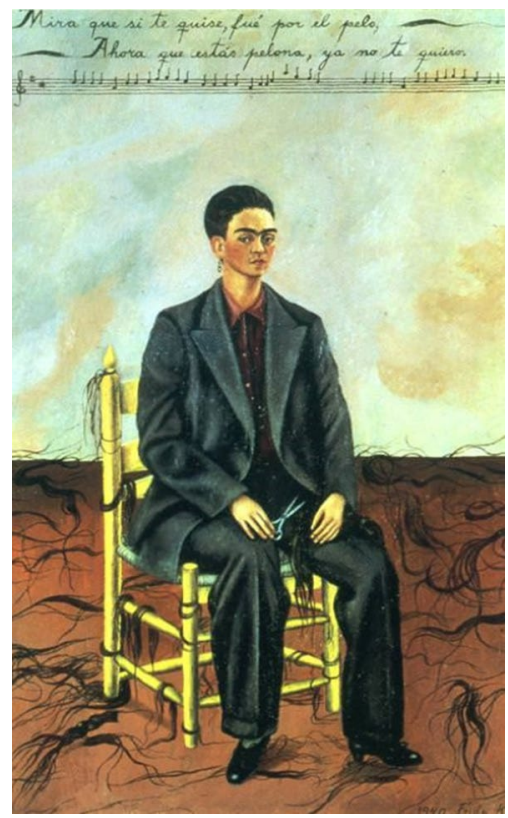

\section{Images of Gender and Identity—Interpictorality and Discursive Positioning}

One of Höglund's pictures from Att vara jag makes visual references to at least two pieces of artwork: Frida Kahlo's Self-portrait with cropped hair from 1940 (Fig. 4) and Lena Cronqvist's Ibland tänker jag på Frida Kahlo [Sometimes I think about Frida Kahlo] from 1986 (Fig. 5). The Kahlo painting depicts the artist on a yellow chair, dressed in a man's oversized black suit, a dark shirt and a necktie. The portrayed Kahlo's long hair is cut short, and tresses of black hair litter the floor. In the self-portrait, Kahlo (1907-1954) holds a pair of scissors in her right hand and black hair in her left hand. Above the depicted woman, there is a line from a Mexican folk song and musical notes, making references to hair as a symbol of femininity and the loss thereof a sign of lost attraction. Artefacts such as earrings and high-heeled shoes traditionally symbolise femininity. Kahlo is said to express her feelings about her divorce from Diego Rivera while also asserting herself as an independent artist (MoMa, 2019).

While Kahlo's Self-portrait with Self-cropped Hair can be found in a number of art books on Frida Kahlo, the second interpictorial hypotext (cf. Genette) for Höglund's hypertext is a painting by the nationally well-known Swedish painter, graphic artist, illustrator and sculptor, Lena Cronqvist (b. 1938).

Between Kahlo's and Cronqvist's paintings, there are both intertextual and interpictorial references. The title of Cronqvist's painting undeniably points in Kahlo's direction, and just like Kahlo, Cronqvist has painted a woman sitting on a chair or stool. She is dressed in pants and a jacket, but unlike Kahlo's figure, the woman in Cronqvist's portrait wears no shirt. Her naked breasts are visible under the jacket. The woman wears flat sandals, not dainty high-heels, and her hair is short. Just like 
Fig. 5 Lena Cronqvist's Ibland tänker jag på Frida Kahlo 1986. Oil and tempera on canvas. $169 \times 125 \mathrm{~cm}$. (C) Lena Cronqvist/Bildupphovsrätt 2021

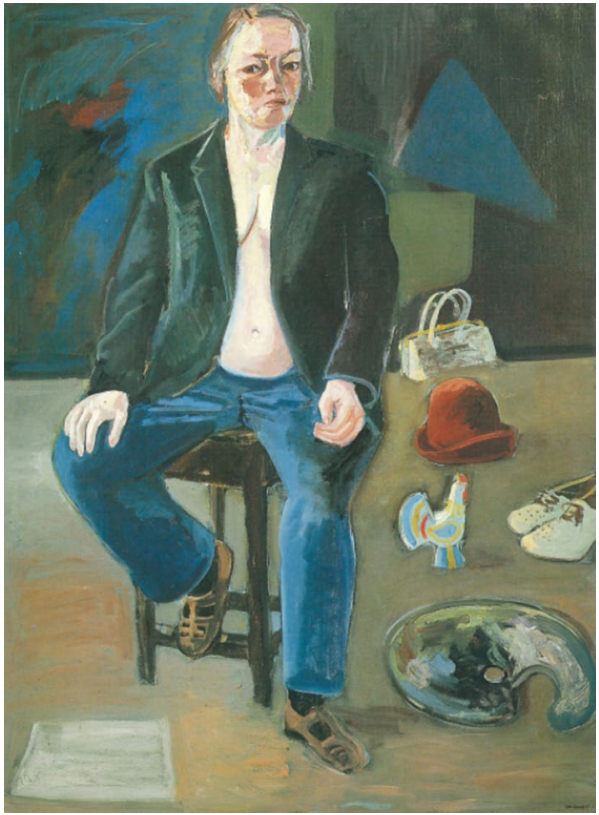

the woman in Kahlo's portrait, Cronqvist's woman comes across as androgynous, despite her breasts. On the floor, a white handbag, a red hat, white heeled brogues, a painted rooster, a painter's palette and what could be interpreted as a piece of paper can be interpreted as traditional symbols of femininity, folk art and art as high culture, respectively. The positioning of the artefacts can be read symbolically, at least partially: the woman in the picture has left behind the handbag, hat and heeled brogues, as well as the painted rooster, thereby no longer primarily defining herself as either a female or a crafts person, although these objects are, or were, or could be interpreted as part of her self-image, too.

In Chapter 2 of Höglund's Att vara jag, there is a spread including text, depicting the protagonist, Rosa, on her bed, legs wide apart (Fig. 6). Rosa is dressed in pants, an open shirt and a necktie. Her hair is short and sticking up, and together with the outfit and her posture, this gives her an androgynous appearance. However, as the shirt is not buttoned, Rosa's breasts are visible, but as they are not particularly prominent, they are not necessarily a gender-specific characteristic. Under the bed lies Rosa's Doppelgänger, in a red dress, eyes closed. Nine big flies are circling in the room, or possibly on the windowpane, if the reader is looking into Rosa's room from the outside. The text reads: "I just want to be me, neither girl nor boy. Just me, without feeling sticky" (Höglund, 2015, Chapter 2. Our translation).

The picture illustrates the gender positions open to the protagonist: male or female, or possibly both. The outfits are, at least from a superficial point of view, gendered: shirt, pants and necktie or dress. The body of the protagonist can, however, be perceived as male or female, which gives the picture an ambiguous position in relation to gender. 


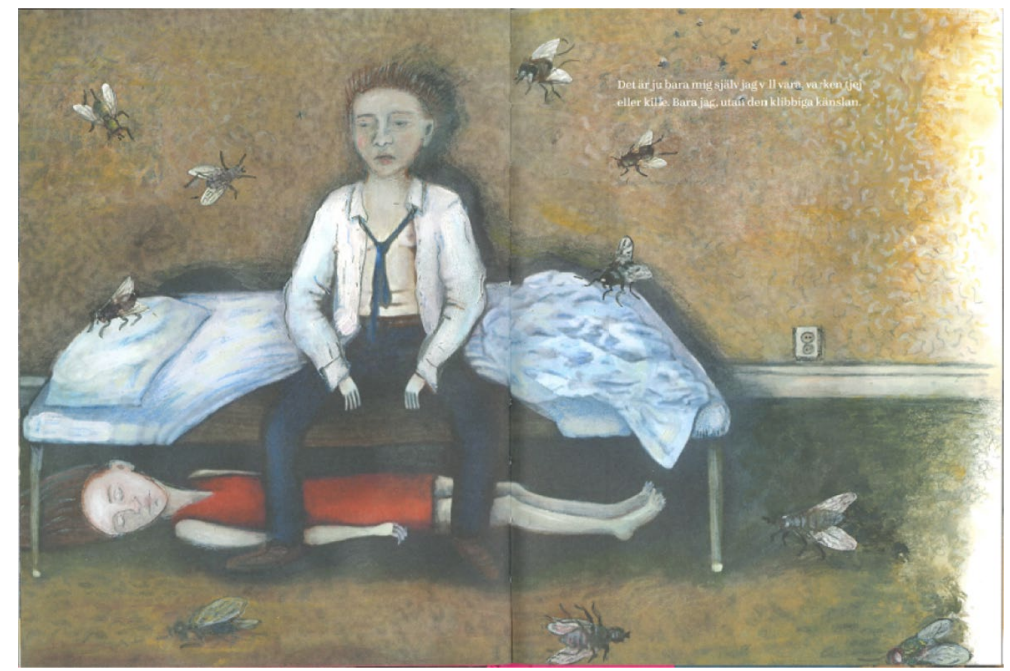

Fig. 6 From Chapter 2 of Anna Höglund's Att vara jag $@$ Anna Höglund

There are numerous visual references between Höglund's picture and the portraits by the Mexican and the Swedish artists. All three images depict an androgynous character, both man and woman. In Höglund's picture, gender is represented in the two versions of the protagonist: the androgynous, or queer, Rosa sitting on the bed, and the Rosa in a red dress lying under the bed, possibly symbolising Rosa's subconscious self, or future self. Both Rosas can be perceived as representing sexuality; the androgynous Rosa on the bed, dressed in a traditional male outfit, and the androgynous Rosa under the bed, in a red dress. The point is that the different representations of the protagonist look the same, are the same. The only difference is the outfit and what it symbolises. The research on the social psychology of dress and colour can be summarised in discussions on the provocative dress as stimuli, and red as a colour associated with lust, fertility and sexuality (Johnson et al., 2014). Thus, Höglund's picture also positions itself in relation to the discourses on sexuality. Rosa is associated with both male and female characteristics, and as a pre-pubescent teenager, it can be argued that her gender is a social construction, mainly signalled through the outfits worn by the two Rosas.

In Kahlo's painting, the outfit, representing an outer layer, can be perceived as male, as suits were not common ladies wear in the Western world in 1940, and neckties are still not primarily associated with women. All three depicted characters have short hair, but all pictures also include elements traditionally associated with women: a dress, breasts, earrings, high-heeled shoes. In all pictures, the character is sitting, legs apart, and all of them are facing forward, although not necessarily looking directly at the viewer. All pictures position themselves discursively in a gender discourse, and although they are from different time periods: 1940, 1986 and 2015, respectively, they are discursively in agreement that gender is a label rather than an identity. Gender is associated with what can be perceived visually: hair, body, body language, garments and artefacts. All three pictures do bring into question the fact 
that the perception of gender is a social construction. It is not entirely the choice of the individual, but also of the viewer. The text accompanying Höglund's picture also verbalises what Kahlo's and Cronqvist's artworks visualise, but the musical notes and lyrics in Kahlo's self-portrait and the title of Cronqvist's painting are not to be overlooked. The lyrics in Kahlo's painting interact with the visual narrative, and the title of Cronqvist's painting complements the visual intertextuality between the two pieces of art. Höglund's text clarifies the discursive positioning of the picture: the refusal to be labelled. Therefore, it is possible to argue that the text and the picture interact in a way that enhances both (cf. Christensen; Nikolajeva and Scott).

\section{Perceptions of Gender and Identity}

Perceptions of gender is a discursive theme in another of Höglund's pictures from Att vara jag, with visual references to a painting by Richard Bergh (1858-1919). Bergh was a Swedish painter and art critic, and from 1915 he was the General Director of the National Museum in Stockholm, in its days the best-known art museum in Sweden. Bergh was one of the most influential Swedish artists from the Nordic national romanticism era at the end of the nineteenth century, and Nordisk sommarkväll [Nordic Summer Evening] from 1899-1900 is regarded as a manifesto for the period. Since the art exhibition Northern Light (1982), Bergh's painting has become widely known. As Michelle Facos (1992) notices, it has met with remarkably different interpretations, according to "the cultural conditioning of the judging eye" (Facos, p. 153).

In Bergh's painting (Fig. 7), a woman and a man stand on a verandah, with a view over open water. There is a lawn in between trees framing the view over the water. Both characters are in half profile and look out over the water. The woman is on the left, and the man is on the right. Colourwise, the man and the woman are opposites, as she is dressed in white, and he is dressed in dark colours, brown and black. Both the man and the woman lean against a pillar, and the knee-high balustrade separates them from the lawn. Apart from the colour of their clothes, the major difference between the man and the woman is their stances; the woman's hands are clasped behind her back, whereas the man's arms are crossed in front of him. In Bergh's painting, there is a small rowing boat anchored to a jetty.

Höglund's picture shares interpictorial references with Bergh's painting. In Höglund's picture, the protagonist Rosa is standing in a living room, in front of the half-open patio door, turned away from the viewer. The patio door opens out to a lawn with a spruce to the left and slim birch trees to the right. Behind the trees, blue water is visible, and on the other side of the waterfront, more grass and trees can be discerned. Rosa is standing with her back to the viewer. She wears a navy blue dress, and its dark colour corresponds with the dark suit of the man in Bergh's painting. On her left, that is in the place of the woman in white in Bergh's painting, there is a white sofa, facing the viewer, not the full-height windows. The text informs the reader that the red stain on the white seat cushion is menstrual blood: 


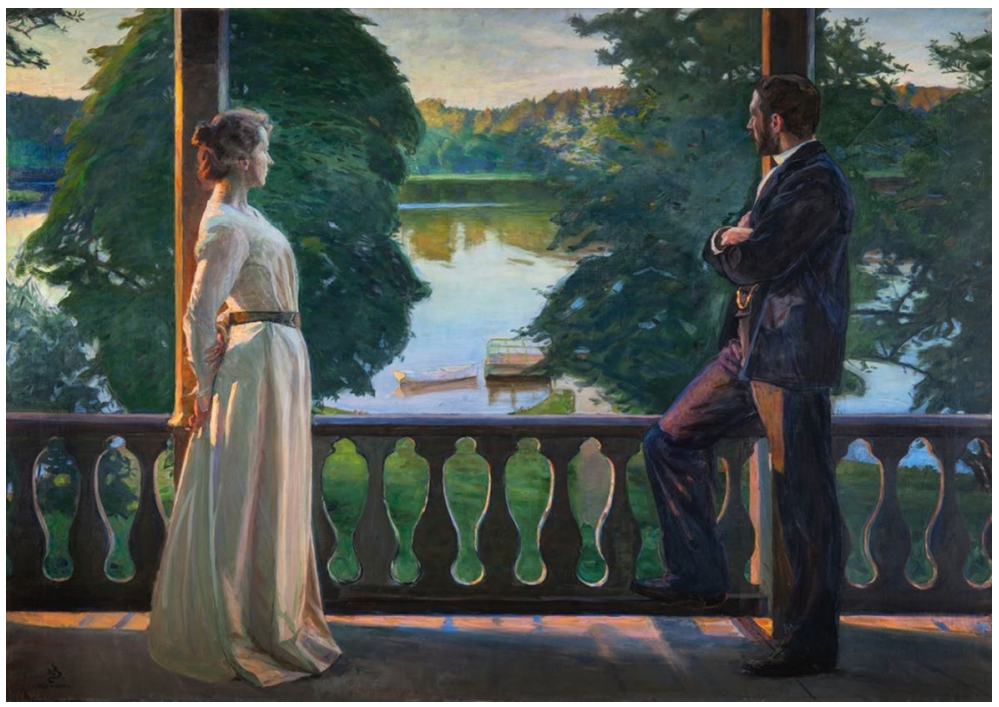

Fig. 7 Richard Bergh (1858-1919), Nordisk sommarkväll 1899-1900. Oil on canvas, $170 \times 223.5 \mathrm{~cm}$. (C) Gothenburg Art Museum

It has happened. I'm having my period. (-) I was very happy, ran and told everyone. Welcome to the club, my cousin Maja said. Then there was a blood stain where I sat on the cousins' white couch. (-) I don't want to be an adult. It doesn't seem fun. But all that, it will come a little by little. Not everything at once. (Höglund, 2015, spread 35. Our translation.)

There are, however, significant differences, too, which makes it possible to argue that Höglund's picture produces a different discursive positioning on gender than Bergh's painting. From the point of view of gender, Bergh's painting and Höglund's paraphrase present different discourses. Gender is binary in Bergh's painting and visualised in positions taken by the man and the woman, and in the choice of colours. Both the woman and the man are looking out of the verandah, onto the surrounding Swedish landscape: dark and light green trees, a calm lake, a green lawn. Both gender representatives are fenced in by the balustrade and the dense, dark trees in the foreground. In Höglund's picture (Fig. 8), the white-clad woman is substituted by a white sofa with a stain of menstrual blood. The sofa is placed to the right in the picture, in front of the full-height window, but it is separated from the outdoors by the transparent but impenetrable glass pane, and it is turned away from the window. Rosa, the protagonist, holds the position corresponding to that of the man in Bergh's painting. Unlike him, she is turned towards the outdoors, and unlike him, she is not visually fenced in. The patio door is ajar, and the way down to the waterfront zigzags between the birch trees. If the reader who is familiar with Bergh's painting sees the white sofa as a metaphor for the female, it is possible to argue that the gender discourse in Höglund's picture points towards the conclusion that gender does not have to be defined in a binary way. Rosa is a female, but she is not entirely defined, 


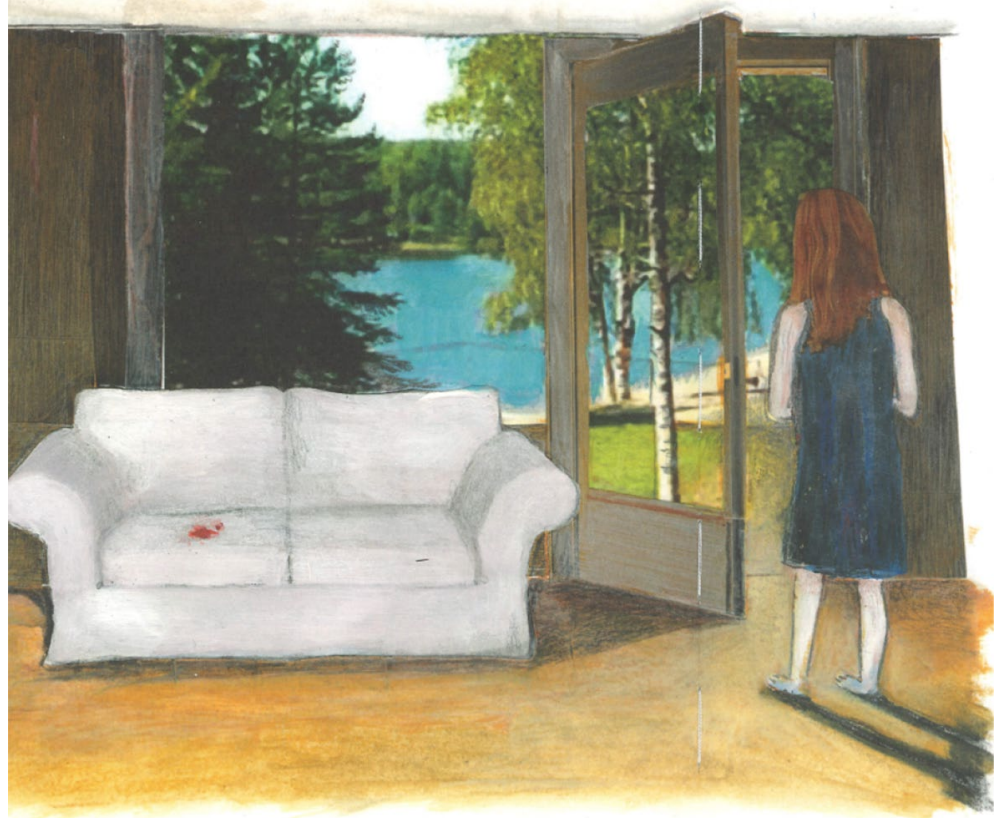

Fig. 8 Picture from Anna Höglund's Att vara jag@ Anna Höglund

or limited, by her gender. She holds the corresponding positions of the man and the woman in Bergh's painting. The text makes it clear that Rosa is connected to the white sofa, as it is her menstrual blood on the sofa cushion. However, gender does not have to be biologically defined, even though both the verbal and the visual narration point at Rosa's physical transition into womanhood. While the man and the woman in Bergh's painting could be seen as accepting their binary position, Rosa turning away from the viewer could be interpreted as not accepting to be defined only as a woman. The white couch, with the blood stain, is facing the viewer; Rosa is not. By juxtaposing the sofa and Rosa in relation to the viewer, Höglund's picture interacts synergetically with the text (cf. Sipe). The positioning of the protagonist, in particular in view of the positioning of Bergh's male and female characters, does however illustrate the fact that neither the text, nor the picture can carry the meaning on its own (cf. Nodelman). While the text signals an acceptance, even the excitement of becoming an adult, Rosa's turning her back at the viewer, facing the half-open door, might be interpreted discursively as a possibility for Rosa to choose her path between the potential, gendered positions. On the other hand, unlike in the Bergh painting, there is no vessel available to help her cross the water.

In using visual references to Bergh's painting, Höglund's picture gives the young reader the opportunity to reflect upon the meaning of Rosa's physical transition from childhood into womanhood and different conditions during the time. Thus, readers familiar with Bergh's painting recognise the contesting gender discourses (cf. 
Arizpe et al.). A reader who has no knowledge of Bergh's painting is unlikely to discern the visual references, but he or she will have to rely on his or her visual and emotional perception (cf. Unrath and Luehrman) and experience of the visualised situation. Readers familiar with Bergh's painting have the possibility of adding a multiplicity of meanings (cf. Sipe and Pantaleo, 2008) when interpreting Höglund's picture which positions itself in a gender and identity discourse.

\section{Understanding and Coming to Terms with Alienation}

As Höglund stated in the interview referred to in the paragraph on Om detta talar man endast med kaniner, pictures "can be helpful to tackle subjects that people find it hard to talk about" (Astrid Lindgren Memorial Award Wordpress, 2014). Alienation is an example of a subject raised in Höglund's book. A spread in Om detta talar man endast med kaniner includes an interpictorial reference to René Magritte's Surrealist painting Le modèle rouge from 1935. In Magritte's painting, the feet show bare toes, with boot shafts instead of ankles. The feet are placed on the ground, directed at the spectator, and with a plank wall behind. Colourwise, Magritte's painting is grey, brown and black (Fig. 9). As Russell Dickerson (2018) points out, Magritte's painting, which exists in different versions, gives the viewer "multiple ideas of what it is to be strange and unsettling". The title of the painting-The Red Model - adds a question, as there is absolutely no red visible in the painting. The human feet made into boots have been interpreted as symbols, for example of "le matérialisme qui aliène l'homme"1 (Arts in the City, 2016), or of "une réalité inventée" (Ottinger, n.d.). ${ }^{2}$.

In Höglund's picture (Fig. 10), the rabbit and her maternal grandfather are in the hallway. The grandfather is on his way out, according to the text: "On our way out, something strange happened. (...) I saw myself when I met my grandfather's gaze. Or, to be more exact: We were the same" (Höglund, 2013, spread 21, our translation). The door is open, and the houses that can be seen lining the street form a slightly curved sightline ahead. The readers' perspective is the same as that of the protagonist. Hence, the readers are looking at the red shoes and meeting the gaze of the man simultaneously as the protagonist does. The man, the rabbit's maternal grandfather, opens the door to the wide world, visualised through the depiction of tall buildings and a blue sky. To the right of the rabbit, a pair of bare feet, resembling those in Magritte's painting - face the rabbit and her grandfather. The light from the opening door is a warm ochre in contrast to the sludgy grey feet protruding from wall. In this picture, the rabbit's legs and human-like hands can be interpreted as a sign of the protagonist, albeit only partially visible in this picture, finding out who he or she is. Discursively, Höglund's picture positions itself differently from Magritte's. The story of the rabbit speaks of alienation, but not of being completely alienated from others: friends, and, in this picture, family. The open door and the red

\footnotetext{
1 The materialism that alienates man.

2 An invented reality.
} 
Fig. 9 René Magritte (18981967), Le modèle rouge 1935 , Oil on canvas, $72 \times 48.5 \mathrm{~cm}$. (C) René Magritte/Bildupphovsrätt 2021

Fig. 10 From Anna Höglund's Om detta talar man endast med kaniner@ Anna Höglund
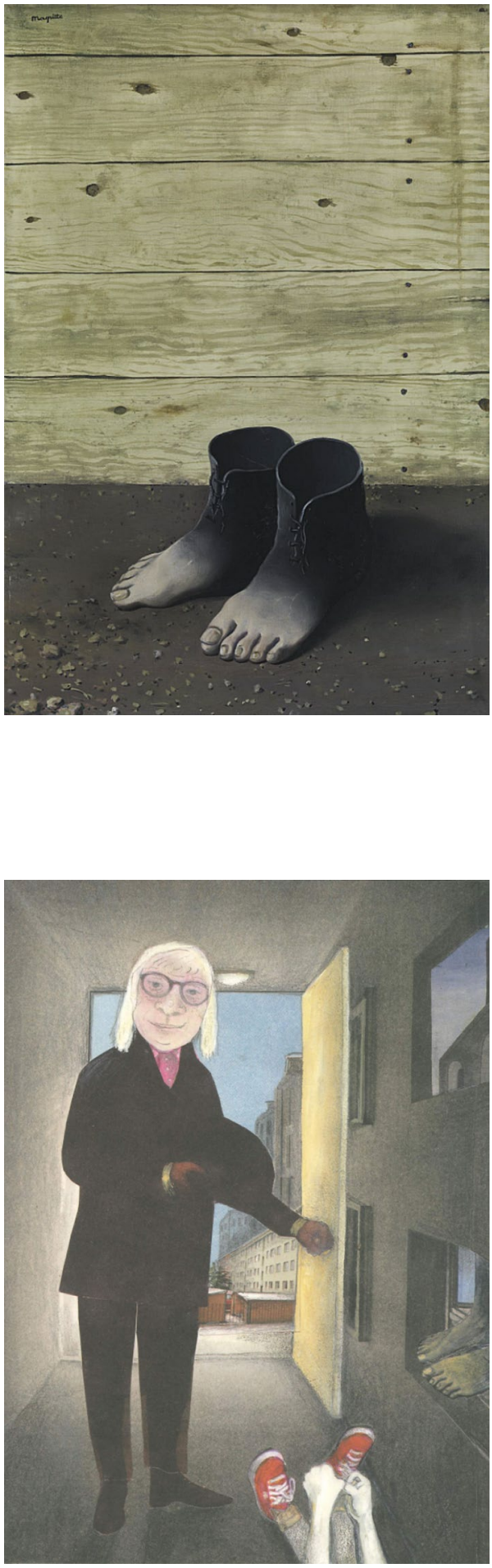
shoes facing forward, as well as the accompanying text, indicate that human beings can feel connected, and have the possibility of navigating between feelings of alienation and sadness. Unlike Andersen's fairy tale, the red shoes in Höglund's picture do not symbolise vanity that must be cut off. Instead, the red shoes might be interpreted as tools for the rabbit protagonist to find his or her way, just like Dorothy in Baum's The Wizard of $\mathrm{Oz}$.

In this case, the text-picture relationship falls in the category of enhancing (Christensen 2018, p. 277). The meeting of gazes is relational and not objectified, or objectifying. The rabbit protagonist has gradually changed throughout the book and resembles a human teenager, and the self-reflections of the rabbit position Höglund's picture in a philosophical and ecocritical discourse (cf. Billing, 2016). Finding oneself, one's identity, is achieved by identifying with other human beings and by putting on one's shoes and walking out into the known, or unknown. In the spreads following this picture, the rabbit protagonist, visually becoming more human, is walking on its own. The reference to Magritte underscores the protagonist's understanding of her/his identity and the way of being human is being part of a world. Furthermore, there is an intertextual reference to a literary text for young readers. In Tove Jansson's short story The Invisible Child (2018), originally published in 1962 in Swedish, the invisible child, Ninni, gradually becomes visible when she is met with kindness, respect and understanding. The last part to become visible in Jansson's story is Ninni's head. In Om detta talar man endast med kaniner, the rabbit visually becomes more human but never changes completely from a rabbit to a human teenager. Nevertherless, to acknowledge one's emotions is pivotal to Ninni, as well as to the rabbit in Höglund's picturebook.

\section{Conclusions}

Initially, we asked the question: Why include art in YA literature for young readers? The analysis of the visual intertexuality between five pieces of artwork and five pictures shows Höglund's interpictorial use of artwork. Visual intertextuality in picturebooks will direct the reader in his or her decoding of the text (cf. Riffaterre), since, supposedly, it challenges the adolescent reader to make connections (cf. Bright) across different media forms. In the case of Höglund's books, the reader faces elements from picturebooks, illustrated novels and, to some extent, graphic novels. The interpretation is a possibility (cf. Blok Johansen). However, the use of art in YA literature goes beyond mere acquisition of a particular cultural capital. By combining recognition and defamiliarisation, visual intertextuality also promotes a critical reading, provided the young readers have access to the decoding skills of reading pictures and reading iconotexts (cf. Hallberg).

It is fairly uncontroversial to state that the interpictorial references made by Höglund to well-known artworks primarily direct knowledgeable readers to canonical artwork from established art styles: the National Romanticism of Bergh's painting, the Modernism of Kahlo's and Cronqvist's paintings, the Realism of Tillberg's painting and Magritte's Surrealism. One might argue that young readers in general are unlikely to recognise the artworks that knowledgeable readers perceive when 
analysing Höglund's pictures, as visual literacy must be taught (cf. Arizpe et al.; Lopatowska et al.). However, the blurring of distinctions between popular and high culture, and the question of intertextuality "made explicit and manifold" (Pantaleo and Sipe, 2012/2008, p. 3) challenge the reader rather than propose a single interpretation. Höglund's interpictorial use of canonical artworks challenges the readers to interpret the iconotext. A secondary, and possibly not intentional effect of using well-known artworks is to offer the young readers an inroad to western art history. The readers of these books might perceive that they have seen the analysed pictures before and see the connections, though their knowledge about the artworks might be less than detailed.

The visual intertextuality in Höglund's works can be perceived as a deeply humanistic project where different traditions help contemporary readers, regardless of their age, to better understand themselves and the world. In that sense, art in YA literature can be perceived as an example of classical Bildung, even though Höglund's main reason for using artworks in her YA literature might not be sprung out of a desire to educate the young readers in fine art (cf. PM Gallery). For young readers who are familiar with picturebooks, illustrated novels and graphic novels, the hybridity of Om detta talar man endast med kaniner and Att vara jag could summarise their reading experiences, from the picturebooks of their childhood to the illustrated novels and graphic novels of their teen years. The interpictorality offers readers new perspectives, defamiliarisation (cf. Druker) and doubt (cf. Biesta). By using traditional features from both picturebooks and YA books, Höglund also challenges and offers a new aesthetic perspective on YA literature in Sweden. Ultimately, the main point when reading Höglund's books might not be to ask why art is used in YA literature, but to see that the visual expression in books like these $i$ art.

Funding Open access funding provided by Lulea University of Technology.

Open Access This article is licensed under a Creative Commons Attribution 4.0 International License, which permits use, sharing, adaptation, distribution and reproduction in any medium or format, as long as you give appropriate credit to the original author(s) and the source, provide a link to the Creative Commons licence, and indicate if changes were made. The images or other third party material in this article are included in the article's Creative Commons licence, unless indicated otherwise in a credit line to the material. If material is not included in the article's Creative Commons licence and your intended use is not permitted by statutory regulation or exceeds the permitted use, you will need to obtain permission directly from the copyright holder. To view a copy of this licence, visit http://creativecommons.org/licen ses/by/4.0/.

\section{References}

\section{Primary Sources}

Höglund, Anna. (2013). Om detta talar man endast med kaniner [This Is Something You Only Talk About with Rabbits]. Stockholm: Lilla Piratförlaget.

Höglund, Anna. Att vara jag [To Be Me]. Stockholm: Lilla Piratförlaget, 2015. 


\section{Secondary Sources}

The Hans Christian Andersen Center. (2020). The Red Shoes. Translation by Jean Hersholt. Department of the Study of Culture, University of Southern Denmark, SDU. Accessed October 19, 2020, at https://andersen.sdu.dk/vaerk/hersholt/TheRedShoes_e.html.

Arizpe, Evelyn, Farrar, Jennifer, and McAdam, Julie (2018). Picturebooks and Literacy Studies. In Bettina Kümmerling-Meibauer (Ed.), The Routledge Companion to Picturebooks (pp. 371-380). London: Routledge.

Arts in the City. (2016). Les pieds dans le plat. René Magritte Le modèle rouge, 1935. Published October 3, 2016. Accessed October 19, 2020 at https://www.arts-in-the-city.com/2016/10/03/le-modelerouge-rene-magritte/.

Astrid Lindgren Memorial Award Wordpress. (2014). Hello There, Anna Höglund. Published July 8, 2014. Accessed October 19, 2020 at https://astridlindgrenmemorialaward.wordpress.com/2014/07/ 08/hello-there-anna-hoglund/.

Baum, L. Frank. (2000). The Annotated Wizard of Oz: the Wonderful Wizard of Oz (Centennial Ed.). Norton, New York.

Biesta, Gert. (2017). Letting Art Teach: Art Education 'After' Joseph Beuys. Arnhem, Netherlands: ArteEz Press.

Billing, AnnaCarin. (2016). Människa, kanin, text och bild i Anna Höglunds Om detta talar man endast med kaniner. In Ingemar Haag (Ed.), Litteratur och språk (pp. 149-156). Eskilstuna, Västerås: Akademin för utbildning, kultur och kommunikation, Mälardalens högskola, no. 11.

Blok Johansen, Martin. (2019). Litteratur og dannelse - at lade sig berige af noget andet end sig selv. København: Akademisk Forlag.

Bright, Amy. (2011). Writing Homer, Reading Riordan: Intertextual Study in Contemporary Adolescent Literature. Journal of Children's Literature, 37(1), 38-47.

Ottinger, Didier. (n.d.). René Magritte Le Modèle rouge [1935]. Le Centre Pompidou, Paris, France. Accessed October 19, 2020, at https://www.centrepompidou.fr/fr/ressources/oeuvre/xBym9Fx.

Christensen, Nina. (2018). Visuelle fortellinger. In Tore Rye Andersen, Jørgen Bruhn, Nina Christensen, Stefan Kjerkegaard, Sara Tanderup Linkis, Birgitte Stougaard Pedersen, and Hans Kristian Rustad (Eds.), Litteratur mellem medier (pp. 269-292). Aarhus: Aarhus Universitetsforlag.

Coats, Karen. (2012/2008). Postmodern Picturebooks and the Transmodern Self. In Lawrence R. Sipe and Sylvia Pantaleo (Eds.), Postmodern Picturebooks: Play, Parody, and Self-Referentiality (pp. 75-88). New York and London: Routledge.

Davies, Bronwyn, and Harré, Ron (1990). Positioning: The Discursive Production of Selves. Journal for the Theory of Social Behaviour, 20(1), 43-63.

Dickerson, Russell. (2018, March 18). This Week's Art: Magritte's Le modèle rouge III. Accessed October 19, 2020, at https://www.rhdickerson.com/2018/03/this-weeks-art-magrittes-le-modele-rouge-iii/.

Druker, Elina. (2018). Collage and Montage in Picturebooks. In Bettina Kümmerling-Meibauer (Ed.), The Routledge Companion to Picturebooks (pp. 49-58). London: Routledge.

Facos, Michelle. (1992). Richard Bergh's Nordic Summer Evening: Cultural Differences in Interpretation. Konsthistorisk Tidskrift, 61(4), 152-160.

Felski, Rita. (2015). The Limits of Critique. Chicago: University of Chicago Press.

Frith, Margaret, and de Paola, Tomie. (2003). Frida Kahlo: The Artist Who Painted Herself (Illustrated Ed.). New York: Grosset \& Dunlap.

Genette, Gérard. (1997). Paratexts. Thresholds of Interpretation. Trans. Jane E. Lewin. Cambridge: Cambridge University Press.

Hallberg, Kristin (1982). Litteraturvetenskapen och bilderboksforskningen [Literary Studies and Picture Book Research]. Tidskrift För Litteraturvetenskap., 3-4, 163-168.

Hoster Cabo, Beatriz, Lobato Suero, María José, and Ruiz Campos, Alberto Manuel. (2018). Interpictorality in Picturebooks. In Bettina Kümmerling-Meibauer (Ed.), The Routledge Companion to Picturebooks (pp. 91-102), London: Routledge.

Jansson, Tove. (2018). The Invisible Child. In Tales from Moominvalley Written and Illustrated by Tove Jansson; Translated by Thomas Warburton. London: Sort of Books.

Johnson, D.B. (2012). Magritte's Marvelous Hat. Boston: HMH Books for Young Readers.

Johnson, Kim, Lennon, Sharon J., and Rudd, Nancy. (2014). Dress, Body and Self: Research in the Social Psychology of Dress. Fashion and Textiles. https://doi.org/10.1186/s40691-014-0020-7. 
Landwehr, Margarete (2002). Introduction: Literature and the Visual Arts; Questions of Influence and Intertextuality. College Literature, 29(3), 1-16.

Lopatovska, Irene, Hatoum, Sarah, Waterstraut, Saebra, Novak, Lisa, and Sheer, Sara (2016). Not Just a Pretty Picture: Visual Literacy Education through Art for Young Children. Journal of Documentation, 72(6), 1197-1227.

Mitchell, Florence S. (1990). Introducing Art History Through Children's Literature. Language Arts, 67(8), 839-846.

MoMa. (2019). Publication excerpt from MoMA Highlights: 375 Works from The Museum of Modern Art, New York. New York: The Museum of Modern Art.

Morgan, Thaïs E. (1985). Is There an Intertext in This Text? Literary and Interdisciplinary Approaches to Intertextuality. American Journal of Semiotics, 3(4), 1-40.

Nel, Philip (2015). Surrealism for children: Paradoxes and possibilities. In Bettina Kümmerling-Meibauer and Elina Druker (Eds.), Children's Literature and the Avant-Garde, (pp. 267-283). Amsterdam: John Benjamins Publishing Company.

Nikolajeva, Maria, and Scott, Carole. (2006). How Picturebooks Work. New York: Routledge.

Nodelman, Perry. (1988). Words About Pictures: The Narrative Art of Children's Picture Books. Athens: University of Georgia Press.

PM Gallery. (2018). Anna Höglund. Published April 18, 2017. Accessed December 20, 2018 at http:// blog.picturebookmakers.com/post/159710751506/anna-höglund.

Riffaterre, Michael. (1981). L'intertexte inconnu. Littérature, 41(1), 4-7.

Rosenstock, Barb, and Grandpre, Mary. (2014). The Noisy Paint Box: The Colors and Sounds of Kandinsky's Abstract Art. New York: Alfred A Knopf; Illustrated Edition.

Salisbury, Martin. (2012/2008). The Artist and the Postmodern Picturebook. In Lawrence R. Sipe and Sylvia Pantaleo (Eds.), Postmodern Picturebooks: Play, Parody, and Self-Referentiality (pp. 22-40). New York and London: Routledge.

Schwarcz, Joseph H. (1982). Ways of the Illustrator. Visual Communication in Children's Literature. Chicago: American Library Association.

Sipe, Lawrence R. (1998). How Picture Books Work: A Semiotically Framed Theory of Text. Picture Relationships. Children's Literature in Education, 29(2), 97-108.

Sipe, Lawrence R., and Pantaleo, Sylvia. (2012). Postmodern Picturebooks: Play, Parody, and Self-Referentiality, 1st ed. London: Routledge.

Thurfjell, Karsten. (2011). Karsten Thurfjell om Blir du lönsam, lille vän? [Karsten Thurfjell on the painting Will you be profitable, dear?]. Sveriges Radio, November 12, 2011. Accessed December 8, 2018 at https://sverigesradio.se/sida/avsnitt/53528? programid=3315.

Unrath, Kathy, and Luehrman, Mick. (2009). Bringing Children to Art-Bringing Art to Children. Art Education, 62(1), 41-47.

Warhola, James. (2005). Uncle Andy's: A Faabbbulous Visit with Andy Warhol. London: Puffin Books.

Publisher's Note Springer Nature remains neutral with regard to jurisdictional claims in published maps and institutional affiliations. 